\title{
Glycogen Storage Disease Type IV, Amylopectinosis
}

\author{
B. LEVIN, E. ANN BURGESS, and PATRICIA E. MORTIMER \\ From Queen Elizabeth Hospital for Children, Hackney Rd., London E.2; and North Middlesex Hospital, London N.18
}

Classification of the glycogen storage diseases according to the underlying enzyme defect has added considerably to our understanding of this group of diseases. Of the 6 types in which the biochemical abnormality has been characterized, the least common appears to be type IV, amylopectinosis. The first case was described by Andersen in 1952, and the glycogen present in the liver and other organs was shown by Illingworth and Cori (1952) to possess abnormally long outer and inner chains of glucose units. For this reason, Cori (1954) suggested that the enzyme, $\alpha-1,4-$ glucan: $\alpha-1,4$ glucan 6-glycosyl transferase, effective in transferring chains of glucose units to form new branches in the glycogen molecule, was absent.

Despite this clear recognition of a new syndrome, few cases have since been reported. A second was diagnosed during life by Sidbury et al. in 1962, and a brief account of a third, also diagnosed in life, was given 3 years later (Mortimer, 1965). Since then, descriptions of 3 more have appeared, 2 of whom were sibs (Holleman, van der Haar, and de Vaan, 1966; Brown and Brown, 1966; Fernandes and Huijing, 1968). In the last 2, absence or gross deficiency of the branching enzyme was conclusively demonstrated by assay.

The present article is concerned with the third case to be reported, of which only preliminary details have previously been given (Mortimer, 1965). Glycogen storage disease was suspected at 8 months of age because of gross hepatomegaly associated with enlargement of the spleen. Investigations of carbohydrate metabolism supported the diagnosis, which was confirmed by an examination of a biopsy specimen of liver. The sparing solubility in water of the glycogen extracted from the liver, and the blue colour of its complex with iodine suggested an amylopectin-like structure, which was proved by a more complete examination.

\section{Case Report}

A boy, the first child of unrelated parents, was born

Received May 2, 1968. at term in hospital on March 4, 1964, after a normal pregnancy and delivery, birthweight $3515 \mathrm{~g}$. For the first 5 weeks he was breast-fed, with dried milk supplements, but thereafter he was fully artificially fed. He gained weight satisfactorily till he was 6 months old, when he began to vomit and ceased to gain. At 8 months of age, he was admitted to hospital because of anorexia as well as persistent vomiting occurring at least once every day. He was then noted to be an alert and active, but wasted child, his weight being on the 3rd centile. The liver, which was firm and smooth, was grossly enlarged to the level of the iliac crest. The spleen was also enlarged to $3 \mathrm{~cm}$. below the costal margin. Initial investigations showed a moderately severe acidosis, treated at first with $M / 6$ sodium lactate, to which after 2 days potassium acetate was added. He ceased to vomit, and improved clinically. An oral glucose tolerance test gave normal results, but the subnormal hyperglycaemic response after injection of adrenaline and glucagon pointed to glycogen storage disease, and a biopsy of the liver was taken. He was discharged, having gained a little weight, on a normal diet, but still having an alkali mixture in the form of sodium citrate and potassium acetate.

He was readmitted when he was 13 months old because of increasing enlargement of the liver and spleen. In an attempt to reduce glycogen deposition in the liver, he was given a low carbohydrate, high protein diet. He improved at first and began to gain weight (Fig. 1). The improvement was short lived however, and he developed ascites, with shortness of breath, for which he was again admitted to hospital. He was in addition slightly jaundiced, the liver was still grossly enlarged with increased splenomegaly, the abdominal vessels were prominent, and there was some oedema of the feet. Neither repeated paracenteses nor infusion of salt-free albumin were effective in reducing the ascites or oedema, nor were diuretics any more successful. The child's condition continued to deteriorate, and he was therefore changed to a low protein diet with increased carbohydrate without effect. A portacaval transposition was performed in the hope of decreasing glycogen deposition in the liver but the child died 24 hours later, in liver failure, when 19 months old. Permission for necropsy was refused.

\section{Material and Methods}

Glucose-6-phosphatase, glycogen synthetase, debrancher enzyme, phosphorylase, and acid maltase 


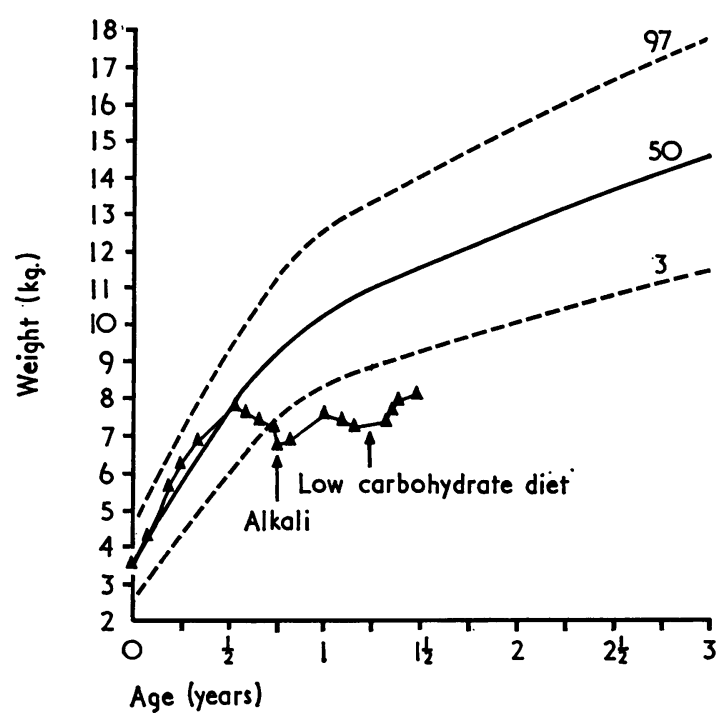

FIG. 1.-Weight chart: note normal weight gain till 3-6 months of age.

were estimated in the liver as described by Hers (1959, 1963), and fructose-1-phosphate and fructose-1 : 6diphosphate aldolase activities as recorded previously (Solimano, Burgess, and Levin, 1967). Ornithine transcarbamylase was determined by a modification of the method of Kulhánek and Vojtišková (1964). The glycogen content, phosphorylase activity, and debrancher enzyme in leucocytes were estimated by methods of Williams and collaborators (Williams and Field, 1961; Williams, Kendig, and Field, 1963). The leucocytes were prepared using a fibrinogen sedimentation technique (Skoog and Beck, 1956).

For the assay of glycogen synthetase, the leucocytes from $15 \mathrm{ml}$. blood were suspended in $0.1 \mathrm{ml}$. sucroseEDTA solution before homogenizing, and the enzyme estimated as in liver.

Blood lactate was estimated by a micro-modification of the enzymatic method of Horn and Bruns (1956), and free fatty acids by a modification of the method of Duncombe (1964).

Glycogen extraction and estimation of glycogen content.

(1) Cold trichloroacetic acid method. $0.5 \mathrm{~g}$. liver was homogenized in $5 \mathrm{ml}$. cold $5 \%$ trichloroacetic acid in water. The precipitated protein was centrifuged and extracted with a further $5 \mathrm{ml} .5 \%$ trichloroacetic acid.

Glycogen was precipitated from the combined supernatant by the addition of an equal volume of absolute alcohol. After allowing to stand for at least 1 hour at $0-4^{\circ} \mathrm{C}$ the precipitated glycogen was removed by centrifugation. It was washed first with $75 \%$ alcohol and then with absolute alcohol and the residue then dried in a desiccator. The glycogen content of the residue was determined by the anthrone method.

(2) Potassium hydroxide method. The glycogen was extracted by adding $1 \mathrm{ml}$. hot $30 \% \mathrm{KOH}$ solution to $0.5 \mathrm{~g}$. liver and heating in a boiling water bath for 30 minutes. After cooling, the glycogen was precipitated with $2 \mathrm{ml}$. absolute alcohol, allowed to stand at $0-4^{\circ} \mathrm{C}$. for 6 hours, and the precipitate separated by centrifugation. It was washed with absolute alcohol and the glycogen content estimated as before.

\section{Glycogen structure.}

Hydrolysis by $\beta$-amylase. $0.8 \mathrm{ml}$. suspension of glycogen containing between $100-500 \mu \mathrm{g} . / \mathrm{ml}$. was incubated at $37^{\circ} \mathrm{C}$. for 4 hours in $0.1 \mathrm{ml}$. $2 \mathrm{M}$ acetate

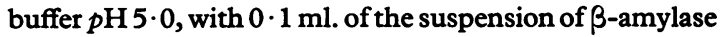
(2 $\mathrm{mg} . / \mathrm{ml}$. in $0.9 \%$ saline). After incubation, an aliquot $(0.5 \mathrm{ml}$.) was neutralized with $0.2 \mathrm{~N}$ sodium hydroxide solution and $0.2 \mathrm{ml}$. each of $0.3 \mathrm{~N}$ barium hydroxide and $5 \%$ zinc sulphate solution were added to precipitate the protein.

The protein-free supernatant $(100 \mu \mathrm{l}$.) was incubated with $100 \mu \mathrm{l}$. maltase suspension $(2 \mathrm{mg} . / \mathrm{ml}$. in glycylglycine buffer, $p \mathrm{H} \mathrm{7 \cdot 2)}$ for 30 minutes. The solution was centrifuged and the glucose formed was estimated in the supernatant using the glucose oxidase method. A standard curve was obtained using solutions containing 25, 50, and $100 \mu \mathrm{g} . / \mathrm{ml}$. maltose estimated as above.

The absorption spectra of the glycogen-iodine complexes were determined on an aqueous solution of the glycogen preparation, containing $0.2 \mathrm{mg} . / \mathrm{ml}$. This was mixed in a cuvette with an equal volume of a solution containing potassium iodide $(0.4 \mathrm{~g} . / 100 \mathrm{ml}$.) and iodine $(0.04 \mathrm{~g} . / 100 \mathrm{ml}$.). The absorption was read at wavelengths between 400 and $600 \mathrm{~m} \mu$ at intervals of $20 \mathrm{~m} \mu$, against a blank containing equal volumes of the iodine/potassium iodide solution and water.

\section{Biochemical investigations.}

Apart from a persistently low bicarbonate ion concentration even on treatment, the plasma electrolytes were within normal limits, except during the period before death, when the plasma sodium fell to $120 \mathrm{mEq} / 1$. The blood urea was also normal except after operation when it rose to $103 \mathrm{mg} . / 100 \mathrm{ml}$. The serum alkaline phosphatase was raised, as were the serum transaminases which remained so throughout his illness. Serum cholesterol was also raised. Initially the total serum protein, albumin, and globulin levels were normal, but as cirrhosis developed, the serum albumin fell and globulin much increased till the few days preceding death, when infusions of plasma and of albumin temporarily restored normal levels. Thymol turbidity, zinc sulphate turbidity, and $\gamma$-globulin turbidity were also normal initially, but later they were all greatly increased. The serum bilirubin examined when clinical jaundice became apparent was slightly raised during the later stages of his illness but more severely just before death. The blood ammonia was also increased $(69 \mu \mathrm{g} . / \mathrm{ml}$. and $99 \mu \mathrm{g} . / \mathrm{ml}$.) at this stage. 


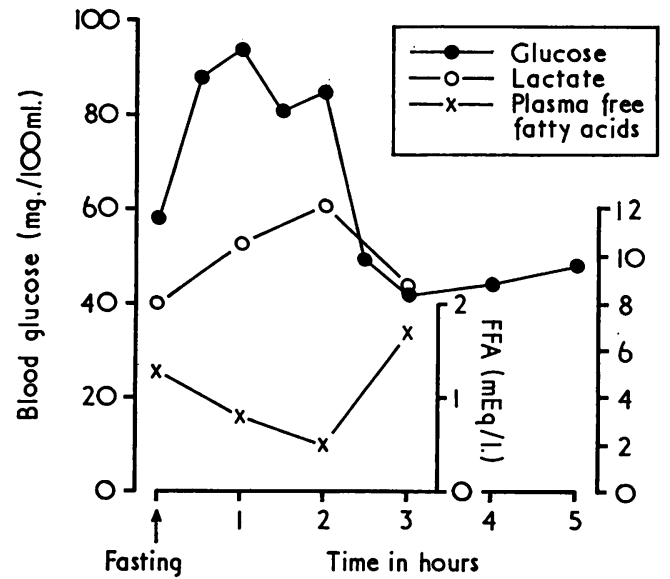

FIG. 2.-Oral glucose tolerance test (1.75 g./kg.). Blood lactate and plasma free fatty acid levels are also shown.

Renal function tests. The hydrogen ion excretion index determined early in the course of the disease was found to be low, $0 \cdot 8$, compared with a normal of greater than 1.2 (Peonides, Levin, and Young, 1966), confirming a renal tubular acidosis. There was neither hyperaminoaciduria nor proteinuria.

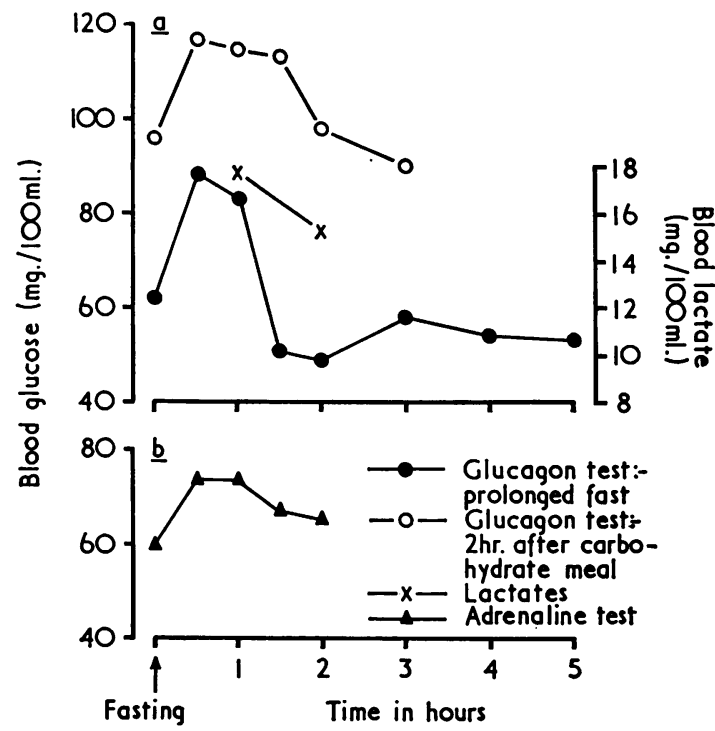

FIG. 4a.-Glucagon test (1mg. I.M.). Lower graph shows blood glucose levels when glucagon was injected after 12-hour fast. Upper graph shows results when glucagon was given 2 hours after a high carbohydrate meal.

Fig. 4b.-Adrenaline test.

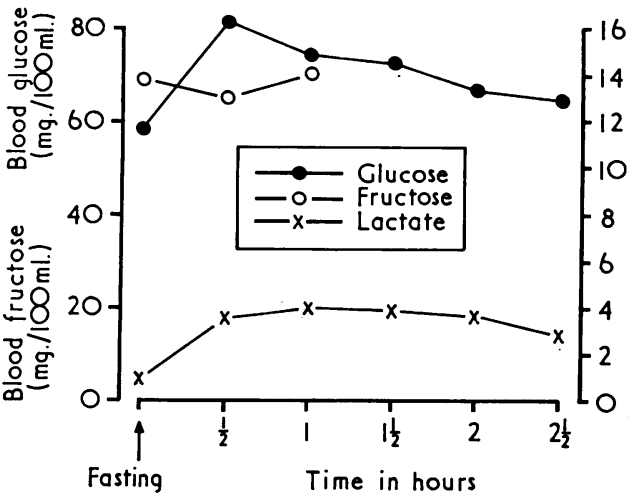

Fig. 3.-Oral fructose tolerance test $(2 \mathrm{~g} . / \mathrm{kg}$.$) . Note$ normal increase of blood glucose level.

Carbohydrate metabolism. There was no evidence of hypoglycaemia throughout the illness, and no ketone bodies were found in the urine except during the glucagon tests. An oral glucose tolerance test on two occasions showed a normal rise in the blood level with normal levels of lactate and free fatty acids (Fig. 2). A fructose tolerance test was also normal, the maximum level of blood fructose being $20 \mathrm{mg}$. per $100 \mathrm{ml}$. In neither case did the blood glucose level fall to hypoglycaemic levels at the end of the test (Fig. 3).

Hepatic glycogenolysis. The glucagon test was done on three occasions. The first was when the infant was $8 \frac{1}{2}$ months old, $700 \mu \mathrm{g}$. glucagon being given intramuscularly. The maximum rise in blood sugar was only $14 \mathrm{mg} . / 100 \mathrm{ml}$., and this occurred as late as 1 hour after the injection. In the second test, when $1 \mathrm{mg}$. glucagon was given intramuscularly, the maximum rise of blood glucose, $27 \mathrm{mg}$. $/ 100 \mathrm{ml}$., occurred 30 minutes after injection (Fig. 4a). The third test, 2 hours after a meal high in carbohydrate, showed a similar rise in blood glucose of $25 \mathrm{mg}$. $/ 100 \mathrm{ml}$. from a high fasting level of $95 \mathrm{mg}$., again 30 minutes after the injection. The urine passed in the last test contained traces of ketone bodies.

The adrenaline test, also performed twice, gave similar results. The first, in which blood sugar was measured, showed a maximum rise of $15 \mathrm{mg} . / 100 \mathrm{ml} .30$ minutes after injection. In the second test (Fig. $4 \mathrm{~b}$ ), the rise in blood glucose was $14 \mathrm{mg} .100 \mathrm{ml}$., also maximal at 30 minutes, with traces of ketone bodies in the urine.

Macroscopical and microscopical appearances of liver. At operation, the liver surface was said to be firm and moderately granular in appearance. The presence of severe portal hypertension was indicated by the grossly dilated porta-systemic anastomoses.

Histology of the liver biopsy showed cirrhosis. The parenchyma cells were enlarged, and the cytoplasm was 
filled with glycogen staining red with Best's stain and dark blue with iodine. This material appeared in two forms, (a) as dense masses in the central area of the cell, relatively insoluble in water and absolute alcohol, and unaffected by incubation at $37^{\circ} \mathrm{C}$. with $\alpha$-amylase for 17 hours and $\beta$-amylase for 36 hours, and (b) as fine granules at the periphery of the cell, which disappeared after incubation with $\alpha$-amylase for only 45 minutes at $37^{\circ} \mathrm{C}$., but were unaffected by $\beta$-amylase.

The blue colour of amylopectin with iodine contrasts with the brown red given by normal glycogen, and this affords a simple method of differentiation from other forms of glycogenoses, including limit dextrinosis. The iodine stain is best done on a frozen section as long fixation reduces or abolishes the blue colour.

Isolation of glycogen from liver. The glycogen content of a specimen of liver obtained at operation was determined after extraction with (a) cold 5\% trichloroacetic acid, yielding 2.4 g./100 g., (b) hot trichloroacetic acid, yielding 3.6 g. $/ 100$ g., (c) hot $30 \%$ potassium hydroxide solution which gave $4.9 \mathrm{~g} . / 100 \mathrm{~g}$. liver.

Structure of liver glycogen. The glycogen obtained by cold trichloroacetic acid extraction differed from that isolated with hot potassium hydroxide in two respects. The former was readily soluble in cold water, and gave a brown-red colour with iodine. The latter was much less soluble and the complex with iodine was blue. Since it was possible that they differed in composition the structures of both were determined.

The absorption spectra of the glycogen-iodine complexes from both specimens are shown in Fig. 5, together with those from (a) normal rabbit glycogen, and (b) glycogen obtained from the liver of a patient with glycogen storage disease type II (Pompe's disease). The maximum absorption of the complex from the glycogen obtained by hot potassium hydroxide was $520 \mathrm{~m} \mu$, suggesting that it was similar to that of amylopectin, which gives the same peak, and different from normal glycogen-iodine complex, which has a peak at $420 \mathrm{~m} \mu$. The absorption curve by trichloroacetic acid-extracted glycogen showed a plateau rather than a peak (Fig. 5), suggesting the possibility that it was a mixture of amylopectin and normal glycogen.

Hydrolysis of the potassium hydroxide-extracted

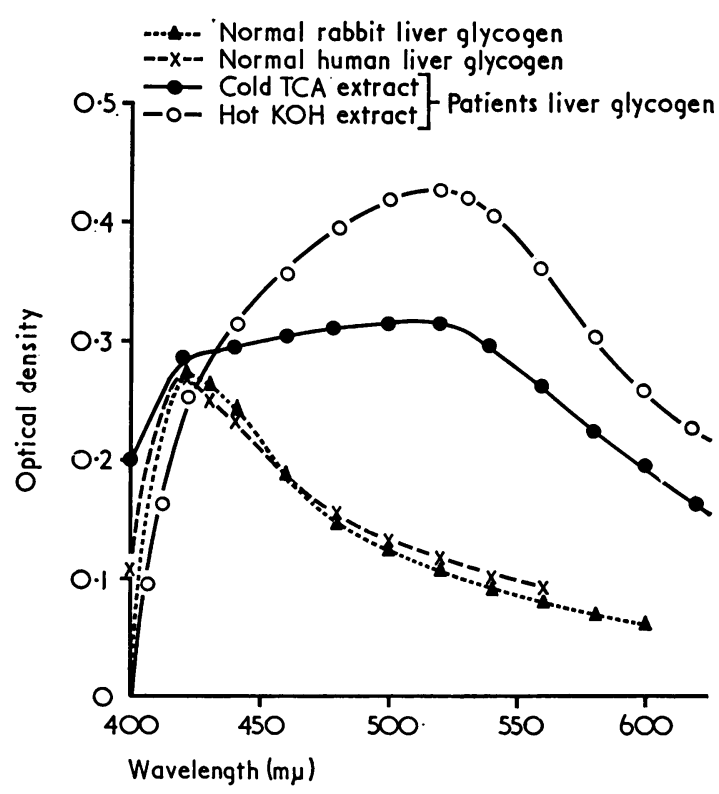

FIG. 5.-Absorption spectra of glycogen-iodine complexes. Note peak of patient's liver glycogen ( $\mathrm{KOH}$ extract) is at $520 \mathrm{~m} \mu$ compared with peak at $420 \mathrm{~m} \mu$ for normal glycogen. The curve for the TCA extracted glycogen is between these two.

glycogen by $\beta$-amylase resulted in a $66 \%$ breakdown to maltose, whereas only $40 \%$ hydrolysis occurred from the action of $\beta$-amylase on the trichloroacetic acidextracted glycogen. The mean chain length of the potassium hydroxide-extracted glycogen, measured by the method of Whelan (Lee and Whelan, 1966), was 22, compared with a normal of 11-14. From this result and the degree of hydrolysis by $\beta$-amylase, the exterior chain length can be calculated to be 17 , compared with a normal of 7-8, while that of the inner branches is 4, compared with the normal of 3-4. The degree of endgroup branching is $4.6 \%$, compared with a normal value of $9 \%$. These results suggested a glycogen with abnormally long outer branches, resembling amylopectin (Table I).

TABLE I

Structure of Liver Glycogen

\begin{tabular}{|c|c|c|c|c|c|}
\hline Case & $\%$ Amylolysis & Chain Length & Exterior Chain Length & Interior Chain Length & Branch Points \% \\
\hline $\begin{array}{l}\text { Present case } \\
\text { Andersen (1952) } \\
\text { Sidbury et al. (1962) } \\
\text { Holleman et al. } \\
\quad \text { (1966) }\end{array}$ & $\begin{array}{c}66 \\
50 \cdot 5 \\
\text { (phosphorylase) } \\
59 \\
57\end{array}$ & $\begin{array}{l}22 \\
21 \cdot 2 \\
- \\
20 \cdot 7\end{array}$ & $\begin{array}{l}16 \\
14 \cdot 7 \\
- \\
14-15\end{array}$ & $\begin{array}{l}4 \\
6 \cdot 5 \\
- \\
5-6\end{array}$ & $\begin{array}{l}3 \cdot 6 \\
3 \cdot 7 \\
- \\
3 \cdot 8\end{array}$ \\
\hline $\begin{array}{l}\text { Normal glycogen } \\
\text { Amylopectins }\end{array}$ & $\begin{array}{l}38-50 \\
50-60\end{array}$ & $\begin{array}{l}12-14 \\
21-24\end{array}$ & $\begin{array}{c}8-9 \\
14-17\end{array}$ & $\begin{array}{l}3-4 \\
5-8\end{array}$ & $\begin{array}{l}6 \cdot 7 \\
3 \cdot 5\end{array}$ \\
\hline
\end{tabular}


TABLE II

Liver Enzyme Activities and Glycogen Content

\begin{tabular}{|c|c|c|}
\hline , & $\begin{array}{l}\text { Present Case } \\
\qquad(\mu \mathrm{M} / \mathrm{g} .\end{array}$ & $\begin{array}{l}\text { Mean Normal Level } \\
\text { per min.) }\end{array}$ \\
\hline \begin{tabular}{lcc} 
Glucose-6-phosphatase & $\ldots$ \\
Acid maltase & $\ldots$ & $\ldots$ \\
Phosphorylase & $\ldots$ & $\ldots$ \\
Glycogen synthetase & $\ldots$ \\
Aldolase F1P & $\ldots$ & $\ldots$ \\
FDP & $\ldots$ &. \\
\multicolumn{4}{c}{ Frnithine transcarbamylase }
\end{tabular} & $\begin{array}{l}5 \cdot 1 \\
0 \cdot 89 \\
13 \cdot 6 \\
0 \cdot 84 \\
1 \cdot 4 \\
3 \cdot 1 \\
37 \cdot 8\end{array}$ & $\begin{array}{c}7 \cdot 4 \\
0 \cdot 62 \\
18 \cdot 7 \\
8 \cdot 0 \\
3 \cdot 9 \\
6 \cdot 4 \\
99 \cdot 1\end{array}$ \\
\hline $\begin{array}{ccrr}\text { Glycogen } & \text { content }(\mathrm{g} . / 100 \\
\text { g.) } & \ldots & \ldots & \ldots\end{array}$ & $4 \cdot 9$ & $<2$ \\
\hline
\end{tabular}

Similar experiments with the trichloroacetic acidextracted material gave a mean chain length of 16 , the exterior branch length being 9 , the inner branch length being 6 , and the end-group branching being $6.2 \%$, which are abnormal values, though less so than the KOH-extracted material.

Liver enzymes of glycogen metabolism It was unfortunately not possible to estimate the activity of the branching enzyme, since only a small amount of liver was available for study and no purified brancher-free phosphorylase-a was available for the assay. However, glucose-6-phosphatase, acid maltase, phosphorylase, and glycogen synthetase activities in the liver were assayed (Table II). The first three were normal, but glycogen synthetase was much reduced, whether rabbit liver glycogen or the glycogen isolated from the liver of the patient was used as substrate for the assay. Two other enzymes, aldolase and ornithine transcarbamylase, were also normal.

Investigations on leucocytes from parents. The glycogen levels in the leucocytes from both parents were normal (Table III). Though insufficient material was isolated to determine the structure, the glycogeniodine complex was normal in colour and showed a peak only at $420 \mathrm{~m} \mu$. Glycogen synthetase, phosphorylase, and debrancher enzyme levels were within normal limits.

\section{Discussion}

This disease may not be as rare as is supposed. Andersen (1964) cites a similar case in the older literature, and it seems likely, as Sidbury et al. (1962) suggest, that the 3 cases of polysaccharide storage disease described by Craig and Uzman (1958) were also amylopectinosis.

From the 5 cases including the present one, of which the clinical details are recorded, a uniform clinical picture of amylopectinosis emerges, which confirms the findings in the description of the original case (Andersen, 1952). The affected infant appears normal at birth and for some months
TABLE III

Leucocyte Enzymes and Glycogen Content in Parents of Affected Infant

\begin{tabular}{|c|c|c|c|}
\hline & Father & Mother & Normal Range \\
\hline $\begin{array}{c}\text { Debrancher enzyme (c.p.m./ } \\
10^{8} \text { cells) }\end{array}$ & $\begin{array}{r}2900 \\
2 \cdot 9\end{array}$ & $\begin{array}{c}1940 \\
1 \cdot 14 \\
4 \cdot 2\end{array}$ & $\begin{array}{c}2200-4820 \\
1 \cdot 3-2 \cdot 7 \\
4 \cdot 5,8 \cdot 3\end{array}$ \\
\hline $\begin{array}{ccrr}\text { Glycogen } & \text { content } & \left(\mu \mathrm{g} . / 10^{7}\right. \\
\text { cells) } & . & . & . .\end{array}$ & $29 \cdot 2$ & $16 \cdot 2$ & $20-38$ \\
\hline
\end{tabular}

thereafter, but early in infancy there is a failure to thrive, and by the sixth month of life abdominal distension due to hepatomegaly, with some splenomegaly, is usually obvious. The child is much below its expected weight, and muscle hypotonia and wasting are also present. As liver and spleen increase in size, the superficial veins over the abdomen become prominent, and ascites develops. Jaundice if present is only slight, being obvious only in the later stages of the illness. Intercurrent infection is frequent, and death occurs from liver failure, in the second year of life, though one child survived to the fouth year. Amylopectinosis may thus be differentiated clinically from the more common glycogenoses, glucose-6-phosphate deficiency, limit dextrinosis, and liver phosphorylase deficiency, which also give rise to hepatomegaly, by the early development of cirrhosis with portal hypertension ending in severe liver failure, and also by the absence of hypoglycaemic episodes.

As in the other forms of glycogenosis, there may be haemorrhagic manifestations in amylopectinosis. These usually take the form of intestinal haemorrhages, presumably due to oesophageal varices. In the present case, purpura was present only in the last stages of the illness when the prothrombin time was greatly increased, and no other haemorrhagic manifestations were noted.

A low carbohydrate diet effected only a shortlived improvement in our case. The effectiveness of portacaval transposition has been claimed in other forms of glycogenosis (Starzl et al., 1965), but it was perfomed too late in our case to achieve a useful result. In the longest surviving patient (Sidbury et al., 1962), steroids were employed over a long period. More recently, $\alpha$-glucosidase, a fungal enzyme prepared from Aspergillus niger, has been used by Baudhuin, Hers, and Loeb (1964) to decrease glycogen concentration in the liver in type II glycogenosis. Fernandes and Huijing (1968) have similarly treated amylopectinosis: they recorded a 
reduction in the liver glycogen content from $10 \cdot 7 \mathrm{~g}$. to 1 or $2 \mathrm{~g} . / 100 \mathrm{~g}$. after intravenous injection of the purified enzyme daily for 6 days, though the fatal course of the disease was not averted. To be effective, treatment should be begun before an irreparable degree of cirrhosis of the liver has occurred.

Carbohydrate metabolism. Oral glucose and fructose tolerance tests were within normal limits, and hypoglycaemia did not develop at the end of the tests. The blood lactate and pyruvate were not unduly raised, as usually occurs in the other forms of glycogenosis in which hepatomegaly is a feature. If a rise in blood glucose of at least $50 \%$ above the fasting level is accepted as the normal response to an adequate glucagon injection, then it was low in the first glucagon test. However, on the second occasion, the rise was almost within normal limits. In the two adrenaline tests, the response was also less than normal. In no case was the fasting blood glucose low. Similar equivocal results were obtained by previous investigators (Sidbury et al., 1962). Though a flat glucose response to glucagon is usual in glucose-6-phosphatase deficiency, this is not always so, and still less so in types III and VI.

Liver and renal functions. The serum transaminases are greatly increased relatively early in the course of the illness, and liver function is invariably grossly impaired by the second year of life, more so than in other forms of glycogenosis. Metabolic renal tubular acidosis, as shown by the low $\mathrm{H}^{+}$clearance index, was also evident early. While acidosis is frequently seen with other types of glycogen storage disease, it is accompanied by, and may be presumed to be due to, the hypoglycaemia and ketosis, while in our case of amylopectinosis, there was a moderately severe acidosis without either. It is likely that the renal tubular defect resulted from an impaired cellular metabolism due to an inability to convert glycogen to glucose in the renal tubular cell, or to excessive deposits of glycogen. No other renal tubular defect was apparent however, e.g. there was no hyperaminoaciduria or glycosuria.

Glycogen content and structure. The glycogen content of the liver is not much raised in amylopectinosis. It was below $5 \mathrm{~g} . / 100 \mathrm{~g}$. in 5 cases, though in one it was as high as $10.7 \mathrm{~g} .100 \mathrm{~g}$. In the present case, the glycogen content was 4.9 g. $/ 100$ g. by $\mathrm{KOH}$ extraction. Though analysis proved this substance to have a long outer and inner chain structure similar to that of amylo- pectin, the data for the glycogen obtained by the less drastic extraction process using cold trichloroacetic acid showed that its structure was closer to that of normal glycogen. Thus, the trichloroacetic acid-extracted material was readily soluble in water like normal glycogen, the colour of the iodine complex was similar to that of the normal glycogen-iodine complex, and the percentage hydrolysis by $\beta$-amylase was within the range for normal glycogen. The absorption spectrum of the iodine complex of the trichloroacetic acid-extracted glycogen suggests that it is a heterogeneous mixture of glycogen molecules, some with relatively normal branching and some with long branch chains. Evidence in favour of this possibility is also afforded by the appearance, on histological examination, of a centrally placed dense mass of glycogen in the liver cell, with finely granular glycogen particles situated peripherally. Holleman et al. (1966) have also suggested that the stored substances in their case of amylopectinosis were heterogeneous, consisting of a mixture of polysaccharides of different branching characteristics, and evidence based on a fractionation of the glycogen from the liver of their case was adduced in support of this possibility by Brown and Brown (1966).

The absence of the branching enzyme in both liver and leucocytes has now been proved in two affected patients (Brown and Brown, 1966; Fernandes and Huijing, 1968). Though this deficiency explains the formation of an amylopectin-like polysaccharide, it does not account for the presence of an appreciable proportion of branch points in the abnormal glycogen, as Hers (1964) points out. Brown and Brown (1966) suggest that two enzymes, with branching activities of different specificities, are present in normal liver, only one of which is measured by the method used. Another possibility is that the mutant gene in this disorder has produced a protein with substantially modified enzyme specificity, such that branching occurs mainly with long outer chains.

Enzymes of glycogen metabolism. The levels of only 4 enzymes of the glycogen pathway were estimated, and the only abnormality detected was a very low glycogen synthetase activity, only $10 \%$ of the mean level found in normal liver. This was not related directly to the abnormal glycogen, since the latter was capable of acting as substrate for mouse liver glycogen synthetase. The glycogen synthetase is sufficiently active in vivo to form glycogen, even if abnormal in structure. However, the very low activity may account for the relatively low liver glycogen content in this con- 
dition compared with that found in other glycogenoses.

Glycogen synthetase has not been assayed in previous cases of amylopectinosis, and the significance of the association of an absent brancher enzyme with severely diminished glycogen synthetase activity is obscure. However, it may be of great theoretical interest as multiple enzyme defects appear to be more frequently reported in glycogen storage disease than in other inborn errors of metabolism (Auerbach and DiGeorge, 1961; Steinitz, 1967). In these cases the enzymes affected have usually been a reduced glucose-6-phosphatase in association with amylo-1:6-glucosidase deficiency, but other double enzyme deficiencies include liver phosphorylase with glucose-6-phosphatase (Lowe et al., 1962) and liver phosphorylase with liver glycogen synthetase (Parr, Teree, and Larner, 1965). From a consideration of the cases reported up to that time, Hers (1964) concludes that the association of two enzymatic defects in one patient or in the same family has not been proved. However, not all those reported can be dismissed as due to imperfect laboratory technique. Multienzyme defects could result from a mutation in an operator gene controlling more than one adjacent enzyme (Jacob and Monod, 1961). Such a possibility is less likely if the gene brancher enzyme is situated on the $\mathrm{X}$ chromosome (see below).

Genetics. Since 2 of the 6 recorded cases were sibs, the condition is inherited, presumably as a recessive character. Though an autosomal inheritance is most likely, the preponderance of males, 5 out of 6 cases, suggests that an X-linked one cannot be excluded. Most types of glycogen storage disease are inherited as an autosomal recessive. Hers (1964) has, however, suggested a dominant mode of transmission in type VI, liver phosphorylase deficiency, to account for the biochemical findings, though Löhr (1965) believes an $\mathrm{X}$ chromosomal recessive inheritance would better accord with the results. No evidence of the heterozygote state could be detected by examination of the leucocytes from both parents.

\section{Summary}

A male infant presented at 8 months of age with persistent vomiting, hepatosplenomegaly, and failure to gain weight for the previous 2 months. The spleen became progressively more enlarged, the superficial abdominal vessels became prominent, and ascites developed. Despite dietary restriction of carbohydrate, he died at the age of 19 months. The glycogen isolated from a biopsy of the liver was sparingly soluble in water, gave a blue colour with iodine solution, and had a mean chain length of 22 glucose units compared with a normal of 11-14. The exterior and interior chains were also longer than normal. Amylopectinosis, Type IV glycogen storage disease, was diagnosed.

In addition to this abnormal form of glycogen, a glycogen more nearly normal in structure was also present in the liver. The liver glycogen synthetase was found to be very low, and this could account for the relatively low liver glycogen content compared with that found in other glycogenoses.

Amylopectinosis may be readily distinguished from the more common forms of glycogenosis, glucose-6-phosphatase deficiency, limit dextrinosis, and liver phosphorylase deficiency, by the early development of cirrhosis with portal hypertension, ending in severe liver failure, as well as by the relatively simple test with iodine. Examination of leucocytes from the parents revealed no evidence of the heterozygote state. Though an autosomal inheritance is more likely, an X-linked one cannot be excluded.

We are grateful to Dr. A. D. M. Jackson, under whose care the patient was admitted to this hospital, to Dr. Patricia Wallis for her help and advice in the diagnosis of this case, to Dr. N. E. France for the histological examination of the liver, and to Professor W. J. Whelan for his assistance in the determination of the glycogen structure.

\section{REFERENCES}

Andersen, D. H. (1952). Studies on glycogen disease with report of a case in which the glycogen was abnormal. In Carbohydrate Metabolism, p. 28. Ed. by V. A. Najjar. Johns Hopkins Press, Baltimore.

- (1964). Glycogen storage diseases and galactosaemia. In Biochemical Disorders in Human Disease, 2nd ed., p. 877. Ed. by R. H. S. Thompson and E. J. King. Churchill, London. Auerbach, V. H., and DiGeorge, A. M. (1961). One gene, more than one enzyme? Von Gierke's disease a case in point. Amer. F. Dis. Child., $102,578$.

Baudhuin, P., Hers, H. G., and Loeb, H. (1964). An electron microscopic and biochemical study of type II glycogenosis. Lab. Invest., 13, 1139.

Brown, B. I., and Brown, D. (1966). Lack of an $\alpha-1,4-$ glucan: $\alpha-1,4$ glucan 6 -glycosyl transferase in a case of type IV glycogenosis. Proc. nat. Acad. Sci. (Wash.), 56, 725.

Cori, G. T. (1954). Glycogen structure and enzyme deficiencies in glycogen storage disease. Harvey Lect., 48, 145.

Craig, J. M., and Uzman, L. L. (1958). A familial metabolic disorder with storage of an unusual polysaccharide complex. Pediatrics, 22, 20.

Duncombe, W. G. (1964). The colorimetric micro-determination of non-esterified fatty acids in plasma. Clin. chim. Acta., 9, 122.

Fernandes, J., and Huijing, F. (1968). Branching enzyme-deficiency glycogenosis: studies in therapy. Arch. Dis. Childh., 43, 347.

Hers, H. G. (1959). Études enzymatiques sur fragments hépatiques. Application à la classification des glycogénoses. Rev. int. Hépat., 9, 35.

- (1963). $\alpha$-Glucosidase deficiency in generalized glycogen storage disease (Pompe's disease). Biochem. F., 86, 11. (1964). Glycogen storage disease. Advanc. Metab. Dis., 1, 1 and 335. 
Holleman, L. W. J., van der Haar, J. A., and de Vaan, G. A. M. (1966). Type IV glycogenosis. Lab. Invest., 15, 357.

Horn, H. D., and Bruns, F. H. (1956). Quantitative Bestimmung von $L(+)$-Milchsäure mit Milchsäuredehydrogenase. Biochem. biophys. Acta (Amst.), 21, 378.

Illingworth, B., and Cori, G. T. (1952). Structure of glycogens and amylopectins. III. Normal and abnormal human glycogen. F. biol. Chem., 199, 653.

Jacob, F., and Monod, J. (1961). Genetic regulatory mechanisms in the synthesis of proteins. F. molec. Biol., 3, 318.

Kulhánek, V., and Vojtišková, V. (1964). On the determination of ornithinecarbamyl-transferase activity. Clin. chim. Acta, $9,95$.

Lee, E. Y. C., and Whelan, W. J. (1966). Enzymic methods for the micro-determination of glycogen and amylopectin, and their unit-chain lengths. Arch. Biochem., 116, 162.

Löhr, G. W. (1965). Pathogenese und Differentialdiagnose der Glykogenosen. Dtsch. med. Wschr., 90, 1549.

Lowe, C. U., Sokal, J. E., Mosovich, L. L., Saricone, E. J., and Doray, B. H. (1962). Studies in liver glycogen disease. Effects of glucagon and other agents on metabolic pattern and clinical status. Amer. F. Med., 33, 4.

Mortimer, P. E. (1965). Glycogen storage disease. Proc. roy. Soc. Med., 58, 700.

Parr, J., Teree, T. M., and Larner, J. (1965). Symptomatic hypoglycemia, visceral fatty metamorphosis, and aglycogenosis in an infant lacking glycogen synthetase and phosphorylase. Pediatrics, 35, 770.

Peonides, A., Levin, B., and Young, W. F. (1966). The renal excretion of hydrogen ions in infants and children. Arch. Dis. Childh., 40, 33.

Sidbury, J. B., Jr., Mason, J., Burns, W. B., Jr., and Ruebner, B. H. (1962). Type IV glycogenosis. Report of a case proven by characterization of glycogen and studied at necropsy. Bull. fohns Hopk. Hosp., 111, 157.

Skoog, W. A., and Beck, W. S. (1956). Studies on the fibrinogen, dextran and phytohemagglutinin methods of isolating leukocytes. Blood, 11, 436 .

Solimano, G., Burgess, E. A., and Levin, B. (1967). Proteincalorie malnutrition: effect of deficient diets on enzyme levels of jejunal mucosa of rats. Brit. F. Nutr., 21, 55 .

Starzl, T. E., Marchioro, T. L., Sexton, A. W., Illingworth, B. Waddell, W. R., Faris, T. D., and Herrmann, T. J. (1965). The effect of portacaval transposition on carbohydrate metabolism: experimental and clinical observations. Surgery, 57, 687 .

Steinitz, K. (1967). Laboratory diagnosis of glycogen diseases. Advanc. clin. Chem., 9, 227.

Williams, H. E., and Field, J. B. (1961). Low leukocyte phosphorylase in hepatic phosphorylase deficient glycogen storage disease. F. clin. Invest., 40, 1841.

-, Kendig, E. M., and Field, J. B . (1963). Leukocyte debranching enzyme in glycogen storage disease. ibid., 42, 656 . 